\title{
Formation and Properties of Nitrocarburizing S-Phase on AISI 316L Stainless Steel-Based WC Composite Layers by Low-Temperature Plasma Nitriding
}

\author{
Shinichiro Adachi *(D), Takuto Yamaguchi and Nobuhiro Ueda
}

Research Division of Metal Finishing and Analysis, Osaka Research Institute of Industrial Science and Technology, 2-7-1 Ayumino, Izumi, Osaka 594-1157, Japan; t_yamaguchi@tri-osaka.jp (T.Y.); ueda@tri-osaka.jp (N.U.)

* Correspondence: shinadachi@tri-osaka.jp; Tel.: +81-725-51-2648; Fax: +81-725-51-2749

Citation: Adachi, S.; Yamaguchi, T.; Ueda, N. Formation and Properties of Nitrocarburizing S-Phase on AISI 316L Stainless Steel-Based WC Composite Layers by LowTemperature Plasma Nitriding. Metals 2021, 11, 1538. https://doi.org/ $10.3390 / \operatorname{met} 11101538$

Academic Editor: Andrea Di Schino

Received: 26 August 2021

Accepted: 22 September 2021

Published: 27 September 2021

Publisher's Note: MDPI stays neutral with regard to jurisdictional claims in published maps and institutional affiliations.

Copyright: (c) 2021 by the authors. Licensee MDPI, Basel, Switzerland. This article is an open access article distributed under the terms and conditions of the Creative Commons Attribution (CC BY) license (https:// creativecommons.org/licenses/by/ $4.0 /)$.

\begin{abstract}
Stainless steel-based WC composite layers fabricated by a laser cladding technique, have strong mechanical strength. However, the wear resistance of WC composite layers is not sufficient for use in severe friction and wear environments, and the corrosion resistance is significantly reduced by the formation of secondary carbides. Low-temperature plasma nitriding and carburizing of austenitic stainless steels, treated at temperatures of less than $450{ }^{\circ} \mathrm{C}$, can produce a supersaturated solid solution of nitrogen or carbon, known as the S-phase. The combined treatment of nitriding and carburizing can form a nitrocarburizing S-phase, which is characterized by a thick layer and superior cross-sectional hardness distribution. During the laser cladding process, free carbon was produced by the decomposition of WC particles. To achieve excellent wear and corrosion resistance, we attempted to use this free carbon to form a nitrocarburizing S-phase on AISI 316 L stainless steel-based WC composite layers by plasma nitriding alone. As a result, the thick nitrocarburizing S-phase was formed. The Vickers hardness of the S-phase ranged from 1200 to $1400 \mathrm{HV}$, and the hardness depth distribution became smoother. The corrosion resistance was also improved through increasing the pitting resistance equivalent numbers due to the nitrogen that dissolved in the AISI 316 L steel matrix.
\end{abstract}

Keywords: plasma nitriding; laser cladding; stainless steel; tungsten carbide; hardness; corrosion resistance

\section{Introduction}

Laser cladding is an effective method for surface modification, such as improving the wear and corrosion resistance of metal substrates, and has many advantages, such as high deposition speed with rapid cooling, dense metallography, strong bonding strength between the cladding layer and substrate, low heat input, and distortion of the substrate [1]. In recent years, the fabrication of three-dimensional objects by additive manufacturing (AM) using laser as a heat source has attracted much attention. There are many metal AM technologies, for example, laser-based powder bed fusion (PBF) methods have two types of selective laser melting (SLM) and selective laser sintering (SLS), in which a laser is irradiated on top of the stacked powders [2-4]. Meanwhile, directed energy deposition (DED) is based on laser cladding with a coaxial nozzle system for feeding powder in the axial direction of the laser beam and has been developed not only as a coating for surface modification, but also as a manufacturing process for various engineering materials and objects. DED achieves a near-perfect net-like shape appearance with faster processing speed and without mold tooling, which can be applied for manufacturing, part repair, and rapid prototyping. DED also enables the reduction in manufacturing costs and has been increasingly used in recent years [5-9].

Among the classes of austenitic stainless steels for laser cladding, AISI 316 L stainless steel is heavily used owing to its excellent corrosion property, high versatility, and the easy of obtaining steel powder [10]. However, deposited AISI 316 L stainless steel layers have 
a low hardness and poor wear resistance properties, and therefore are difficult to use in severe wear conditions. Several researchers have reported methods to improve the wear resistance and strength of deposited steel layers, and it is concluded that the addition of carbide particles as a reinforcement is highly effective. When the hard carbide particles were dispersed in the steel matrix, the steel structure was modified to one akin to sintered metal matrix composite materials. Consequently, the wear resistance is significantly improved [11-13].

It is required that reinforcement carbides have high hardness, chemical affinity to steel, and high melting temperature $[14,15]$. Tungsten carbide (WC) is a hard ceramic that can be uniformly dispersed in a steel matrix with good wettability; therefore, WC particles have been considered as excellent candidates for reinforcement. Steel-WC composite layers are currently the most widely applied for hardness and strength characteristics $[16,17]$. As for AISI $316 \mathrm{~L}$ stainless steel layers, it has been reported that the properties of the cladding layers were improved by compositing with $\mathrm{SiC}, \mathrm{TiC}$ and titanium carbonitride [18-20]. As a matter of course, the WC particles composite for AISI 316 L stainless steel layers obtained by the laser cladding process also leads to improved mechanical properties, in particular, surface hardness and wear resistance [21-23]. During the heating of the laser cladding process, the WC particles decompose and solidify in the AISI $316 \mathrm{~L}$ steel matrix, and consequently, the steel matrix structure modifies to form carbide networks as a dendritic structure $[21,22,24]$. In addition, $\mathrm{WC}, \mathrm{W}_{2} \mathrm{C}$ phases, $\mathrm{M}_{23} \mathrm{C}_{6}$, and $(\mathrm{Fe}, \mathrm{W})_{3} \mathrm{C}$ complex carbide phases form, and tungsten and carbon elements solidify [25].

In this way, the wear resistance of WC composite layers can be improved by the hardness of WC particles themselves and also by the formation of carbides in the stainlesssteel matrix. However, the hardness of stainless-steel matrix is not sufficient compared with that of hard materials such as ceramics. In addition, when a higher amount of WC particles is added, cracks will appear in the composite layer [26]. Therefore, there is a limit to the amount of WC particles, and the effect of improving wear resistance is also limited. Recently, the fabrication of coatings and objects by laser cladding and DED has attracted considerable attention, especially because of its high functionality for use in severe environments. Accordingly, in addition to the composite of WC particles, further enhancement of wear resistance by other methods should be investigated.

Low-temperature plasma nitriding and carburizing at temperatures less than $450{ }^{\circ} \mathrm{C}$ for austenitic stainless steels can improve their wear resistance. Rather than producing a nitride or carbide, this treatment produces supersaturated solid solution of nitrogen or carbon in the face-centered cubic lattice, which is known as the S-phase (or the expanded austenite) [27-33]. Accordingly, the corrosion resistance does not degrade because the ability to form a passive film is maintained after plasma treatment $[34,35]$. In addition, a combined treatment of nitriding and carburizing has advantages of thickening and improving the toughness of the S-phase compared with the individually nitriding and carburizing [36-39].

These plasma treatments have been applied not only to steel plates but also to thermal spray coatings and laser cladding of AISI $316 \mathrm{~L}$ stainless steel, and their effectiveness has been recognized by the authors [27-30]. In addition, the effects of alloy elements in stainless steel plates on the formation and properties of the S-phase have also been examined, and several papers have reported the role of chromium, nickel and molybdenum [32,40-42]. The increase or decrease in these alloy elements causes a variation in the thickness of the S-phase layer and influences the wear and corrosion properties. Furthermore, the nickel element of stainless-steel layers fabricated by laser cladding was reported by the authors [30]. However, the effects of tungsten and tungsten carbides on the S-phase have not yet been reported for both steel plates and cladding layers.

The WC composite layers contain free carbon produced by the decomposition of the WC particles during laser cladding process. In general, a nitrocarburizing S-phase requires two processes of nitriding and carburizing continuously or simultaneously. Through the use of this free carbon, there is a possibility that a carburizing S-phase is formed 
by nitriding process alone. In this study, AISI $316 \mathrm{~L}$ stainless steel-based WC particle composite layers were fabricated using laser cladding, subsequently performed by lowtemperature plasma nitriding. Consequently, a thick nitrocarburizing S-phase had formed. Therefore, the metallurgical changes and carbide formation of the WC composite layers during laser cladding process were examined in detail. The formation mechanism of the nitrocarburizing S-phase by low-temperature plasma nitriding were investigated, and the properties of the hardness and corrosion resistance with the WC content were discussed.

\section{Experiments}

AISI 316L stainless steel-based WC composite layers were obtained using direct laser metal deposition. The mixed powder of AISI $316 \mathrm{~L}$ stainless-steel powder with $20 \mathrm{wt} . \%$ or $40 \mathrm{wt} . \%$ of tungsten carbide (WC) powder was used as a material for the laser cladding. The powder diameter was $-212 /+63 \mu \mathrm{m}$ of AISI $316 \mathrm{~L}$ stainless-steel powder, and $-180 /+53 \mu \mathrm{m}$ of WC powder.

The laser cladding system consisted of a continuous-wave diode laser beam machine of LDM-2000-60 (Laserline, GmbH, Mulheim-Karlich, Germany) with an attached a coaxial powder feed head of COAX12 (Fraunhofer, Munchen, Germany). The condition of the laser beam was a wavelength of $940 \mathrm{~nm}$ and an output power of $1.4 \mathrm{~kW}$. The laser head was scanned one-layer deposition on AISI 304 stainless steel plates (size of $65 \mathrm{~mm} \times 65 \mathrm{~mm} \times 10 \mathrm{~mm}$ ) with a traverse speed of $4 \mathrm{~mm} \mathrm{~s}^{-1}$ and length of $50 \mathrm{~mm}$ at $3 \mathrm{~mm}$ interval. The mixed powder was delivered in the coaxial direction of the laser beam through the COAX12 laser head with mass flow rates of $17-19 \mathrm{~g} \mathrm{~min}^{-1}$, and using argon as the carrier gas.

To remove the surface oxidation film and flatten the surface profile such as a mirror, the deposited AISI 316 L stainless steel-based WC composite layers were polished, and the final polishing was treated using a $1 \mu \mathrm{m}$ diamond paste. After the polishing, the thickness of the deposited layers was over $1 \mathrm{~mm}$.

DC plasma ion treatment machine of FECH-1N (Fuji Electronics Industry, Osaka, Japan) was used in low-temperature plasma nitriding. The AISI 316L stainless steel-based WC composite layers on the AISI 304 stainless steel plate were connected to a cathode electrode in the glass chamber, and the copper plate was connected to an anode electrode. DC current was applied between the anode and cathode electrode at a voltage of $300 \mathrm{~V}$. The plasma gas with a composition ratio of $\mathrm{N}_{2}: \mathrm{H}_{2}=80: 20$ flowed at a rate of $1 \mathrm{~L} \mathrm{~min}^{-1}$ in the chamber to keep the pressure at $667 \mathrm{~Pa}$. The nitriding temperatures were at $400{ }^{\circ} \mathrm{C}, 425^{\circ} \mathrm{C}$ and $450{ }^{\circ} \mathrm{C}$, and the processing time was $4 \mathrm{~h}$ after reaching the nitriding temperatures.

The crystal structure of the WC composite layers was examined using an X-ray diffraction measurement of SmartLab (Rigaku, Tokyo, Japan) in the conventional $\theta-2 \theta$ scan of a $\mathrm{Cu}-\mathrm{K} \alpha$ radiation with $40 \mathrm{kV}$ and $150 \mathrm{~mA}$.

Cross-sectional micrographs of the WC composite layers were obtained using an optical microscope of ECLIPSE MA100N (Nikon, Tokyo, Japan). The thickness of the nitride layers was measured from the cross-sectional micrographs at approximately 60 points for each sample.

The compositions of the WC composite layers were investigated by SEM with an energy-dispersive X-ray (EDX) analysis, SEM of ERA-8900FE (Elionix, Tokyo, Japan), and EDX of ApolloX (AMETEK, Berwyn, IL, USA), and the operating SEM voltage was $20 \mathrm{kV}$. In addition, the nitrogen and carbon depth distribution profiles were obtained using a glow-discharge optical emission spectroscopy (GDOES) of GDA750 system (Rigaku, Tokyo, Japan).

The hardness depth profiles in the cross-section of the nitrided layers were measured using a nanoindentation tester of ENT-1100a (Elionix, Tokyo, Japan) with a test load of $1.5 \mathrm{mN}$. The measurements for each sample were repeated thrice. The surface hardness of the WC composite layers was measured using a Vickers tester of HM-220D (Mitutoyo, Tokyo, Japan) with a test load of $0.245 \mathrm{~N}$. The Vickers tests were repeated for each sample at least eight times, and the maximum and minimum values were rejected. 
The corrosion resistance of the WC composite layers was estimated from anodic polarization curves. The anodic polarization curves were obtained using a potentiostat of HSV-110 (Hokuto Denko Corporation, Tokyo, Japan). The reference and counter electrode were an $\mathrm{Ag} / \mathrm{AgCl}$ and a platinum plate, respectively. The measurement voltage was applied at a range of $-0.6 \mathrm{~V}$ to $1 \mathrm{~V}$ with a scan rate of $1 \mathrm{mV} \mathrm{s}^{-1}$. The experiments were carried out in a $3.5 \mathrm{wt} . \% \mathrm{NaCl}$ solution at a temperature of $30^{\circ} \mathrm{C}$. Before the measurements, the dissolved oxygen in the $\mathrm{NaCl}$ solution was degassed by bubbling with $\mathrm{N}_{2}$ gas for at least $0.5 \mathrm{~h}$. After the measurements, the corrosion morphologies of the surfaces were obtained using a digital microscope of Dino-Lite (AnMo Electronics Corporation, Taipei, Taiwan).

\section{Results and Discussion}

\subsection{Carbide Formation of AISI 316 L Stainless Steel with WC Particles during Laser Cladding}

Figure 1 shows an overall view of the cross-section of $20 \mathrm{wt} \% \%$ and $40 \mathrm{wt} . \%$ of WC particle composite layers. Note that the WC compositions in the text are the content of the feeding powder material used for the laser cladding, and the compositions of the deposited layers should be varied during the laser cladding process. The WC particles were dispersed in the AISI $316 \mathrm{~L}$ steel matrix, similarly to the metal matrix composite materials. However, cracks perpendicular to the substrate were observed in some areas of the WC 40 wt.\% layers.

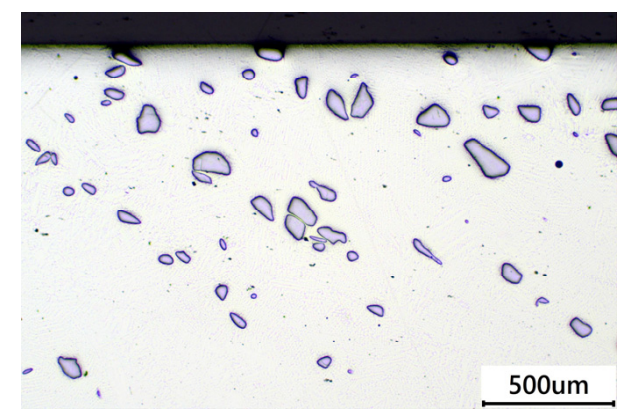

(a)

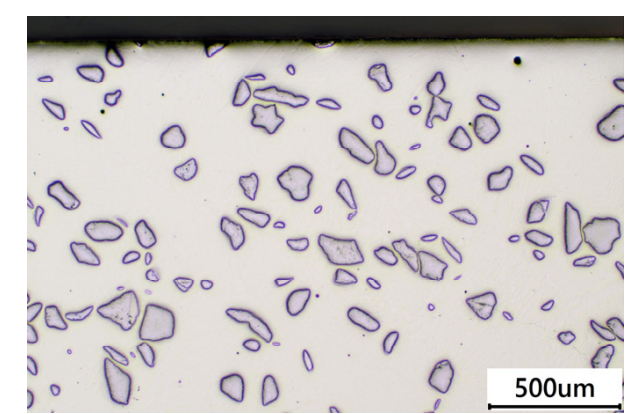

(b)

Figure 1. Cross-sectional micrographs of the as-deposited AISI 316 L steel-based WC composite layers with various WC compositions: (a) WC $20 \mathrm{wt} . \%$, and (b) WC $40 \mathrm{wt} . \%$.

The XRD patterns in Figure 2 present that the as-deposited WC composite layers contained the austenite phase of AISI $316 \mathrm{~L}$ stainless steel, the carbides of $\mathrm{WC}, \mathrm{W}_{2} \mathrm{C}$ and $\mathrm{M}_{6} \mathrm{C}$, and $\mathrm{M}_{12} \mathrm{C}$ in only the $40 \mathrm{wt}$.\% layer. It has been reported that $\mathrm{WC}, \mathrm{W}_{2} \mathrm{C}$ phases, $\mathrm{M}_{23} \mathrm{C}_{6}$, and $(\mathrm{Fe}, \mathrm{W})_{3} \mathrm{C}$ complex phases are formed simultaneously in Fe/WC metal matrix composite coatings produced using the $\mathrm{Yb}$ : YAG laser [25].

Furthermore, $\mathrm{W}_{2} \mathrm{C}$ carbide is produced by the decomposition of $\mathrm{WC}$, the metastable $\mathrm{W}_{2} \mathrm{C}$ decomposes to $\mathrm{M}_{6} \mathrm{C}$ of $\mathrm{Fe}_{3} \mathrm{~W}_{3} \mathrm{C}[43,44]$, and the Eta-carbides of $\mathrm{M}_{6} \mathrm{C}$ and $\mathrm{M}_{12} \mathrm{C}$ are formed in the quaternary system Fe-W-C-Cr [45]. In this examination, the WC particles in the deposited layers were decomposed to $\mathrm{W}_{2} \mathrm{C}$; subsequently, $\mathrm{W}_{2} \mathrm{C}$ decomposed and reacted with the AISI $316 \mathrm{~L}$ steel. Finally, the secondary carbides of $\mathrm{M}_{6} \mathrm{C}$ and $\mathrm{M}_{12} \mathrm{C}$ were synthesized. In Figure 3 of the cross-sectional microstructures after the etching treatment with Marble's reagent $\left(5 \mathrm{~mL} \mathrm{HCl}, 5 \mathrm{~mL} \mathrm{H}_{2} \mathrm{O}\right.$, and $\left.1 \mathrm{~g} \mathrm{CuSO}_{4}\right)$, the gray contrasting areas with a net-like appearance in the AISI $316 \mathrm{~L}$ steel matrix indicate the precipitation of $\mathrm{M}_{6} \mathrm{C}$ and $\mathrm{M}_{12} \mathrm{C}$ as secondary carbides.

The magnified image by SEM in Figure 4 also showed the presence of eutectic carbides between the austenite in the WC $40 \mathrm{wt}$.\% layer. In addition, elemental analysis of SEM-EDX showed that tungsten was dissolved in the austenite, and the chemical compositions of $\mathrm{W}$ ranged from 10 to $15 \mathrm{wt} . \%$. 


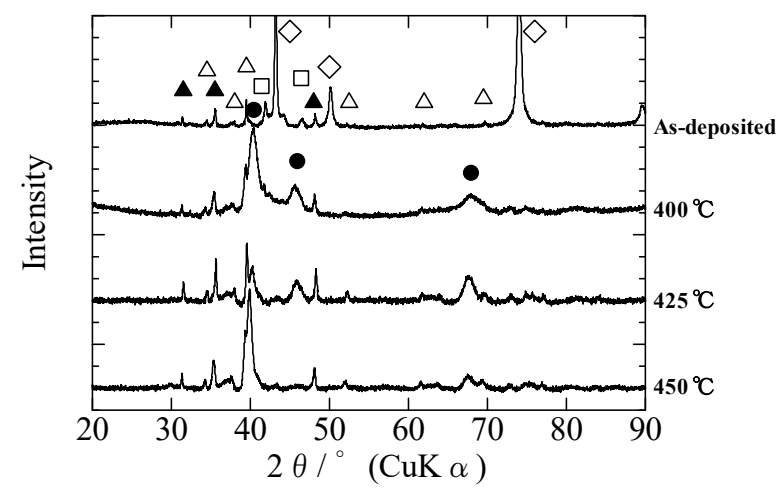

S-N phase, $\Delta \mathrm{WC}, \triangle \mathrm{W}_{2} \mathrm{C}$, $\square \mathrm{M}_{6} \mathrm{C}, \diamond \gamma$ phase

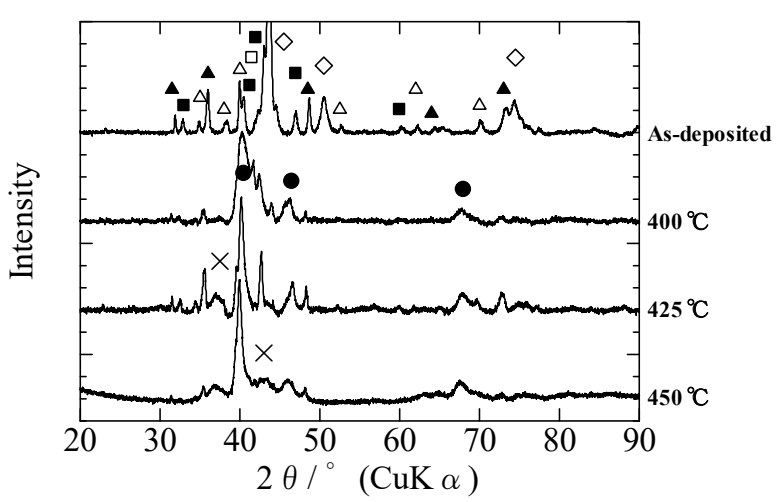

S-N phase, $\boldsymbol{\Delta} \mathrm{WC}, \triangle \mathrm{W}_{2} \mathrm{C}, \square \mathrm{M}_{6} \mathrm{C}$,

$\mathrm{M}_{12} \mathrm{C}, \times \mathrm{CrN}, \diamond \gamma$ phase

(a)

(b)

Figure 2. X-ray diffraction patterns of the AISI $316 \mathrm{~L}$ steel-based WC composite layers with various WC compositions and nitriding temperatures: (a) WC $20 \mathrm{wt} . \%$, and (b) WC $40 \mathrm{wt} . \%$.

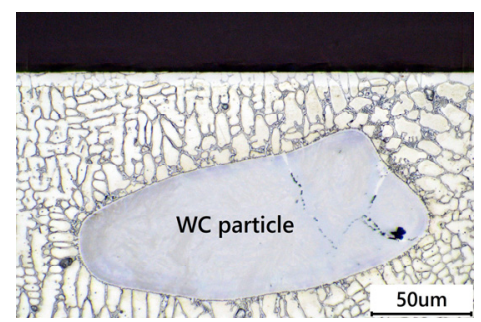

(a)

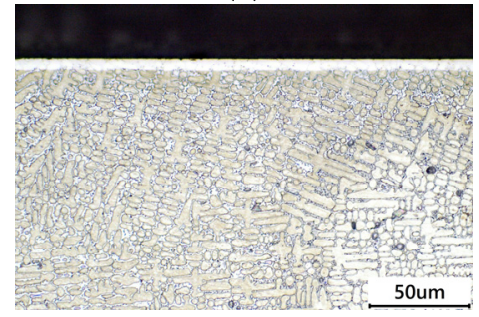

(d)

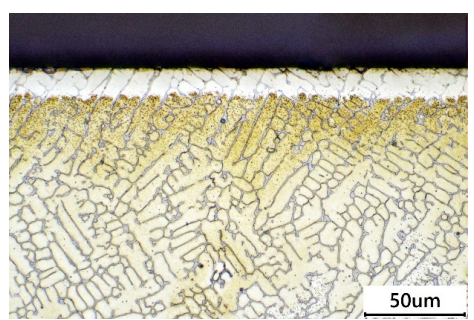

(b)

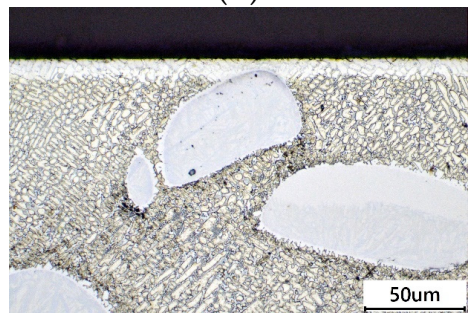

(e)

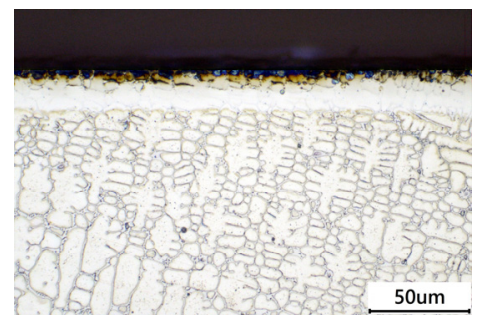

(c)

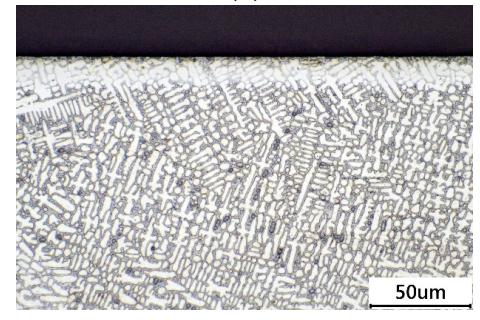

(f)

Figure 3. Cross-sectional micrographs of the AISI $316 \mathrm{~L}$ steel-based WC composite layers with various WC compositions and nitriding temperatures: (a) WC $20 \mathrm{wt} . \%$ at $400{ }^{\circ} \mathrm{C}$, (b) WC $20 \mathrm{wt} . \%$ at $425^{\circ} \mathrm{C}$, (c) WC $20 \mathrm{wt} . \%$ at $450{ }^{\circ} \mathrm{C}$, (d) WC $40 \mathrm{wt} . \%$ at $400{ }^{\circ} \mathrm{C}$, (e) WC $40 \mathrm{wt} . \%$ at $425^{\circ} \mathrm{C}$, and (f) WC $40 \mathrm{wt} . \%$ at $450{ }^{\circ} \mathrm{C}$.

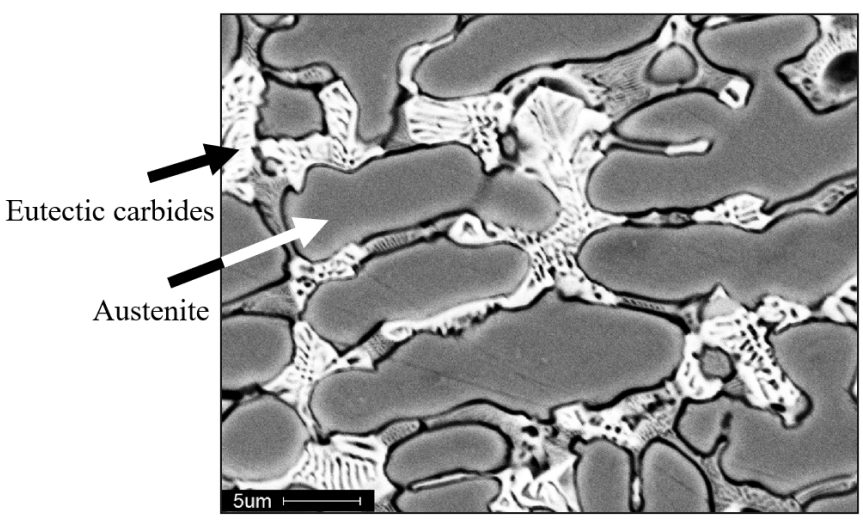

Figure 4. Cross-sectional SEM image of the AISI $316 \mathrm{~L}$ steel-based WC $40 \mathrm{wt}$.\% composite layer. 


\subsection{Formation Mechanism of Nitrocarburizing S-Phase by Plasma Nitriding}

The XRD of the nitrided WC composite layers in Figure 2 show that the (111), (200) and (220) planes of the $\gamma$-phase shifted towards the lower angles than those of the as-deposited layers. These shifts of the $\gamma$-phase peaks are caused by expanding the fcc lattice constants due to the dissolution of nitrogen. In addition, the cross-sectional microstructures with the etching treatment in Figure 3 indicate that the bright contrast layers are present on the surface. These XRD peak shifts and presence of the bright contrast layers suggest the formation of the S-phase.

Figure 5 shows the thickness of the S-phase measured from the bright contrast layers in the cross-sectional microstructures (Figure 3). The average thickness of the S-phase increased with increasing nitriding temperature. WC $20 \mathrm{wt} . \%$ layers were $6.7 \mu \mathrm{m}$ at the nitriding temperature of $400{ }^{\circ} \mathrm{C}, 13.5 \mu \mathrm{m}$ at $425^{\circ} \mathrm{C}$, and $20.6 \mu \mathrm{m}$ at $450{ }^{\circ} \mathrm{C}$. WC $40 \mathrm{wt} . \%$ layers were $5.6 \mu \mathrm{m}$ at $400{ }^{\circ} \mathrm{C}, 9.8 \mu \mathrm{m}$ at $425^{\circ} \mathrm{C}$, and $15.7 \mu \mathrm{m}$ at $450{ }^{\circ} \mathrm{C}$.

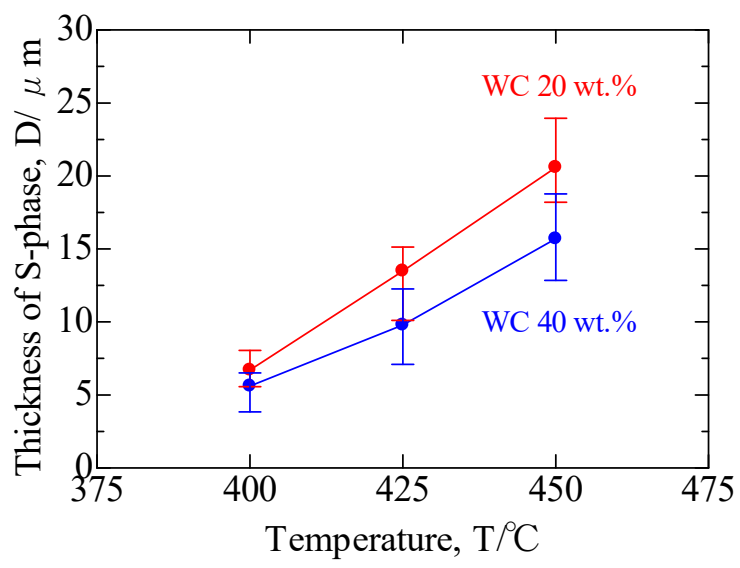

Figure 5. Thickness of the S-phase layers with various WC compositions and nitriding temperatures.

The nitrogen depth distributions of the S-phase obtained by the GDOES measurements in Figure 6, show that nitrogen's distribution is plateau and step-like, rather than a smooth decrease which would obey Fick's law. Plateau and step-like distributions have been reported due to the dissolved chromium atoms binding to nitrogen, and it is considered that these distributions are unique to the S-phase [46-48]. Meanwhile, the carbon distributions show that the carbon peaks are present at a greater depth than where the nitrogen diffusion had completed. These distributions of carbon are very similar to that obtained by continuously or simultaneously nitriding and carburizing treatments [36-38]. Furthermore, the thickness of the S-phase, measured from the bright contrast layers in the cross-sectional microstructures (Figure 5), was thicker than the diffusion depth of nitrogen in GDOES. The thickness was almost equal to the sum of the diffusion depth of the nitrogen and the depth of the peak position of carbon. These results suggest that a carburizing S-phase presents where the carbon peaks exist.

The source of carbon in the carburizing S-phase seems to be free carbon produced by the decomposition of $\mathrm{WC}$ to $\mathrm{W}_{2} \mathrm{C}$ during the laser cladding process, since the possibility of decomposition of carbides by nitriding is low from the point of view of thermodynamics. Furthermore, some WC particles may have dissolved due to the local temperature increase caused by the laser scanning [49]. It is also possible that free carbon derived from the formation of the secondary carbides, $\mathrm{M}_{6} \mathrm{C}$ and $\mathrm{M}_{12} \mathrm{C}$. It has been reported that the diffusion rate of carbon in austenitic stainless steels is fast compared with that of nitrogen [36]; therefore, the free carbon could penetrate ahead of nitrogen due to the nitrogen pushing the free carbon inward during the plasma nitriding, finally the carburizing S-phase would be formed. Consequently, the S-phase became a dual layer of nitrocarburizing; the nitriding S-phase sited at the outside, and the carburizing S-phase at the inside. 


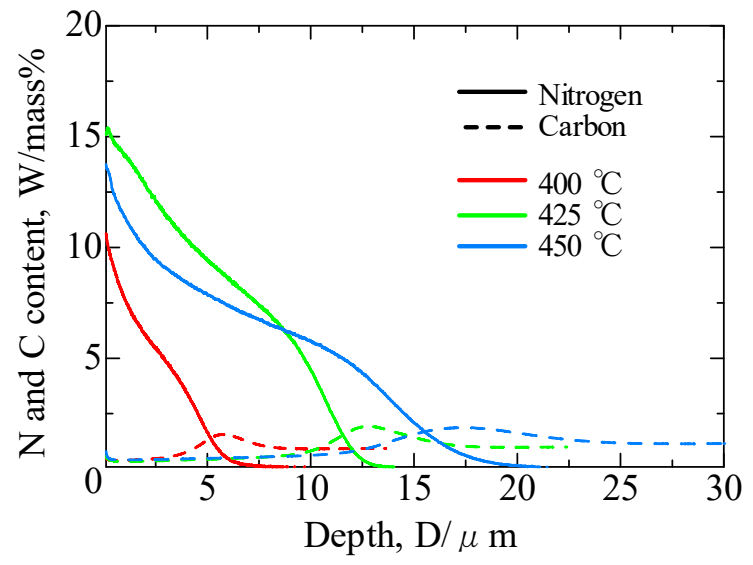

(a)

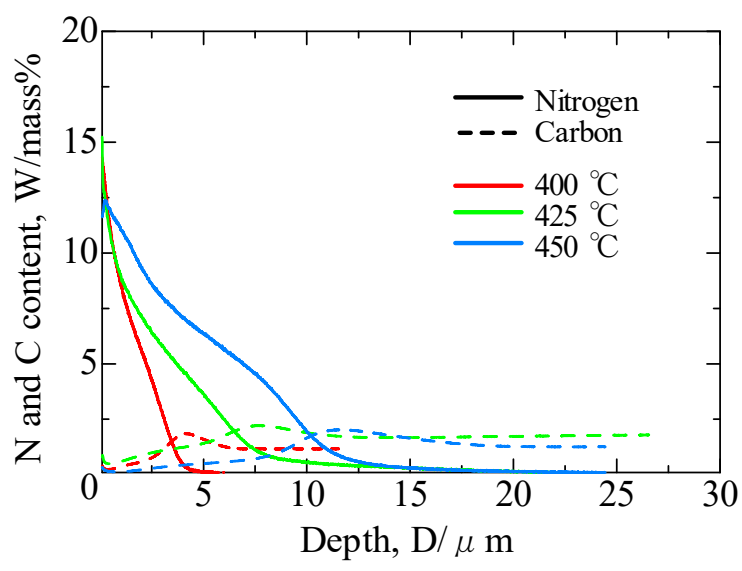

(b)

Figure 6. Nitrogen and carbon depth distributions of the AISI $316 \mathrm{~L}$ steel-based WC composite layers with various WC compositions and nitriding temperatures: (a) WC $20 \mathrm{wt} . \%$, and (b) WC $40 \mathrm{wt} . \%$.

\subsection{Effects of WC Content on Thickness of Nitrocarburizing S-Phase}

The thickness of the S-phase of the WC composite layers was greater than that of $8.2 \mu \mathrm{m}$ of the single AISI $316 \mathrm{~L}$ steel layer without WC at $450{ }^{\circ} \mathrm{C}$ [30]. The formation of the carburizing layer as well as the nitriding layer has resulted in the thickening of the S-phase. The GDS result for WC $20 \mathrm{wt} . \%$ at $450{ }^{\circ} \mathrm{C}$ in Figure 6 presents the nitrogen plateau region reaching up to $12 \mu \mathrm{m}$ depth. Even excluding the carburizing S-phase, the nitriding S-phase was thicker than that of the single AISI 316 L steel layer. As shown in the previous section, the compositions of the solid solution of tungsten in the austenite ranged from 10 to $15 \mathrm{wt} . \%$. Therefore, the solid solution of tungsten may promote nitrogen diffusion.

Meanwhile, comparing the nitrogen diffusion depth between the $20 \mathrm{wt} . \%$ and $40 \mathrm{wt} . \%$ WC layers in GDOES (Figure 6), the WC $40 \mathrm{wt} . \%$ layers diffused at a much shallower rate. The WC $40 \mathrm{wt} . \%$ layers had dense secondary carbide precipitations of a net-like appearance (Figure 3), resulting in the decrease in the crystal grain size. These dense carbide precipitations and small grain size would prevent the nitrogen diffusion. In contrast, the thickness of the carburizing S-phase (width of the carbon peaks in Figure 6) was almost the same in both layers. The WC $40 \mathrm{wt} . \%$ layers had a higher volume of the free carbon. Therefore, the shallow diffusion of nitrogen would not change the thickness of the carburizing S-phase layers.

\subsection{Hardness Depth Profiles and Vickers Hardness of Nitrocarburizing S-Phase}

Figure 7 shows the nanoindentation hardness-depth profiles of the cross-section at a nitriding temperature of $450{ }^{\circ} \mathrm{C}$. The hardness gradually decreased from the surface to the inside, and hardening was observed up to a depth of approximately $20 \mu \mathrm{m}$ for the $20 \mathrm{wt} . \%$ layer and $15 \mu \mathrm{m}$ for the WC $40 \mathrm{wt} . \%$ layer. These hardening depths are almost identical to the thickness of the S-phase (Figure 5). In general, hardness depth profiles formed by nitriding alone have been reported to abruptly decrease at the boundary between the S-phase layer and the base metal. In contrast, a combined treatment of nitriding and carburizing decreases gradually from the surface to the inside [50]. Therefore, these hardness depth profiles also prove the formation of the carburizing S-phase. The variations in hardness in the deep region where the S-phase was not formed are likely due to the hardness of the secondary carbides. From these variations, the hardness of the secondary carbides was derived to be 10-20 GPa, which is lower than the hardness of the surfaces of the nitriding S-phase layers. 


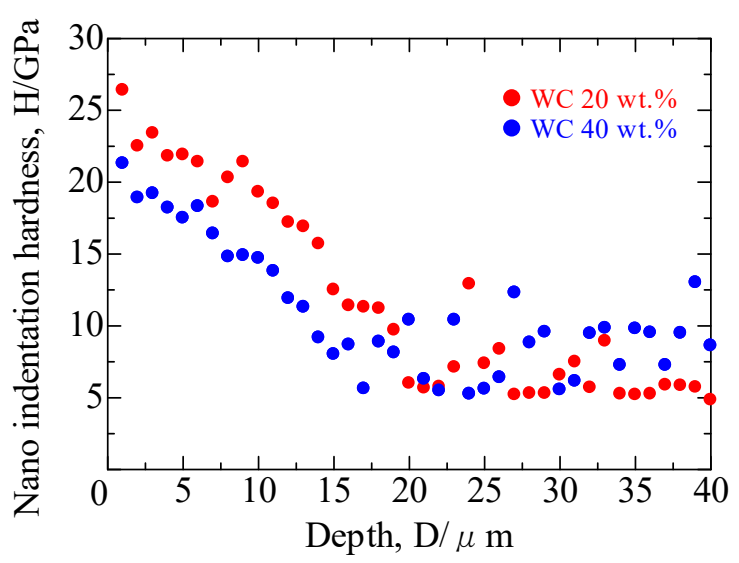

Figure 7. Hardness depth profiles of the S-phase layers at the nitriding temperature of $450{ }^{\circ} \mathrm{C}$ with various WC compositions.

The Vickers hardness values of the surfaces of the WC composite layers are shown in Figure 8. The Vickers indentations were aimed at the surfaces of the AISI 316 L steel matrix, except for the WC particle location. The average hardness of the as-deposited $20 \mathrm{wt} \%$ and $40 \mathrm{wt} . \% \mathrm{WC}$ layers was $540 \mathrm{HV}$ and $654 \mathrm{HV}$, respectively. Meanwhile, the single AISI 316 L steel layer without WC was 205 HV [30]. Therefore, the composite of WC particles improved the hardness of the as-deposited WC composite layers by more than $300 \mathrm{HV}$. The reason for this improvement owes to the formation of secondary carbides and the dissolved solid solution of tungsten. In addition, the hardness of the as-deposited $40 \mathrm{wt}$.\% layer was $100 \mathrm{HV}$ harder than that of the WC $20 \mathrm{wt}$ \% layer because more secondary carbides existed.

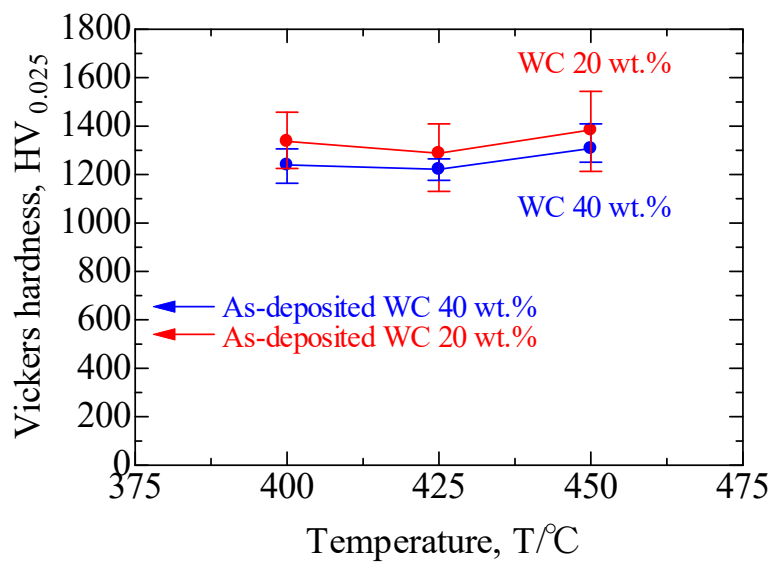

Figure 8. Vickers hardness of the surfaces of the as-deposited and nitrided layers with various WC compositions and nitriding temperatures.

In contrast, the average hardness of the S-phase at a nitriding temperature of $450{ }^{\circ} \mathrm{C}$ was $1384 \mathrm{HV}$ for the $20 \mathrm{wt}$ \% layer and $1308 \mathrm{HV}$ for the WC $40 \mathrm{wt}$ \% layer. This hardness was almost the same as that of the S-phase on the single AISI 316 L steel layer without WC [30]. As mentioned above, the hardness of the secondary carbides was lower than that of the nitriding S-phase. Therefore, after plasma nitriding, the secondary carbides and solid solution of tungsten are not effective in improving the hardness. On the contrary, the WC $40 \mathrm{wt}$ \% layers had a low hardness compared to the WC $20 \mathrm{wt}$.\% layers, suggesting that an increase in WC content decreases the S-phase hardness because the many secondary carbides with low hardness are present.

In consequence, the composite of WC particles only improved the hardness of asdeposited AISI 316 L steel matrix, not improved the S-phase hardness. However, the nitrocarburizing S-phase was formed by the composite of the WC particles, that has the 
advantage of smoothing the hardness depth distribution, which is expected to restrict the delamination of the S-phase layer from the substrate when an external force is applied [50].

\subsection{Corrosion Resistance of Nitrocarburizing S-Phase}

Figure 9 shows the anodic polarization curves of the as-deposited and nitrided layers. The as-deposited WC $20 \mathrm{wt} . \%$ layer had a narrower passive region, and the WC $40 \mathrm{wt} . \%$ layer had no passive region.

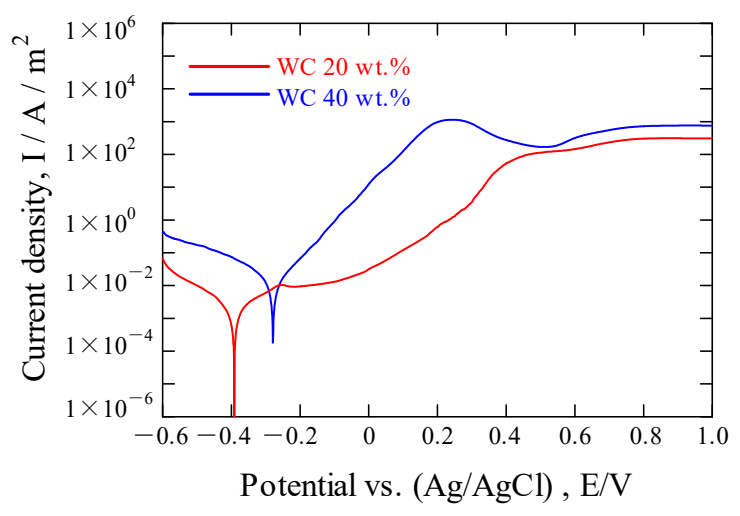

(a)

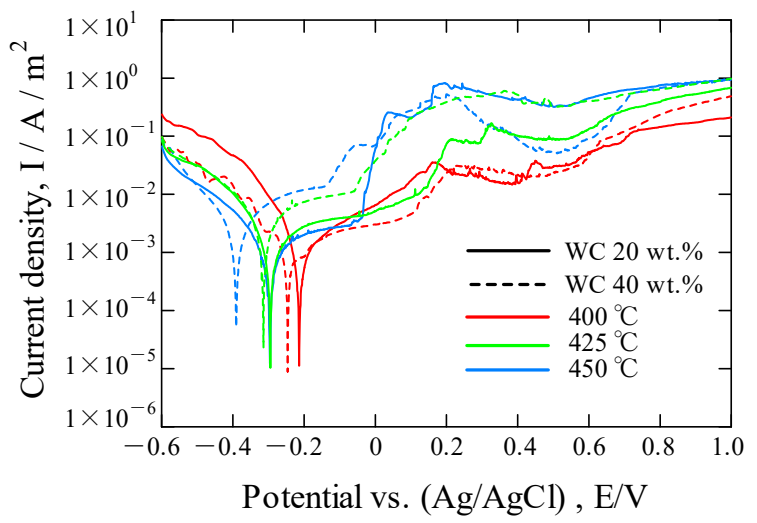

(b)

Figure 9. Anodic polarization curves in 3.5 mass $\% \mathrm{NaCl}$ solution of the as-deposited and nitrided layers with various WC compositions and nitriding temperatures: (a) of as-deposited layers, and (b) of nitrided layers.

The absence of a passive region implies a low corrosion resistance. These results indicate that the WC composite layers were inferior to the single AISI $316 \mathrm{~L}$ steel layer without WC [30]. In general, the effect of alloying elements on the pitting resistance of various types of stainless steels reported that $\mathrm{Cr}, \mathrm{Mo}, \mathrm{W}$, and $\mathrm{N}$ strongly influence the pitting resistance equivalent numbers (PREN) as per Equation (1) [51].

$$
\text { PREN }=\% \mathrm{Cr}+3.3 \times(\% \mathrm{Mo}+0.5 \% \mathrm{~W})+16 \times \% \mathrm{~N}
$$

The solid solution of tungsten in the AISI $316 \mathrm{~L}$ steel matrix can improve the PREN. However, elemental analysis of SEM-EDX indicated that the compositions of chromium were approximately $11-13 \mathrm{wt} . \%$ of both the $20 \mathrm{wt} . \%$ and $40 \mathrm{wt} . \%$ WC layers, which showed a decrease compared to $17 \mathrm{wt} . \%$ of the feeding AISI $316 \mathrm{~L}$ steel powder. Passive films on austenitic stainless steels are composed of oxy-hydroxides of iron, chromium, and molybdenum species [52]; in particular, chromium oxy-hydroxides play an important role. Therefore, the decrease in the solid solution of chromium would degrade the passive film. Furthermore, secondary carbides should also prevent the uniform formation of the passive film on the AISI $316 \mathrm{~L}$ steel matrix. Therefore, the as-deposited WC composite layers exhibited a poor corrosion resistance.

In contrast, the nitrided WC composite layers had a passive region, and the corrosion current density was generally lower than that of the as-deposited layers. Figure 10 shows that the surfaces of the as-deposited layers exhibited pitting corrosion around the boundary of the tested area $(5 \mathrm{~mm} \times 5 \mathrm{~mm})$, while the nitrided layers were discolored slightly, and no pitting corrosion was observed. Note that the black dots visible on the nitrided layers were not pitting corrosion, but WC particles. The dissolved nitrogen greatly improves the PREN; therefore, the formation of the S-phase improved the corrosion resistance.

The corrosion current density of the $40 \mathrm{wt} . \%$ layers was higher than that of the WC $20 \mathrm{wt}$.\% layers because containing more secondary carbides would increase the corrosion current. In addition, the XRD pattern in Figure $2 \mathrm{~b}$ indicates small $\mathrm{CrN}$ peaks in WC $40 \mathrm{wt} . \%$ layers treated at nitriding temperatures of $425^{\circ} \mathrm{C}$ and $450{ }^{\circ} \mathrm{C}$. The formation of $\mathrm{CrN}$ can also 
decrease the solid solution of chromium to deteriorate the corrosion resistance. Therefore, increasing the WC content would deteriorate the corrosion resistance. For the same reason, the S-phase of the WC composite layers was inferior to that of the single AISI $316 \mathrm{~L}$ steel layer without WC [30].

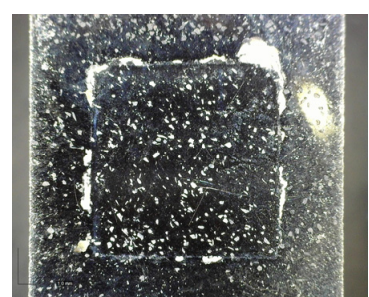

(a)

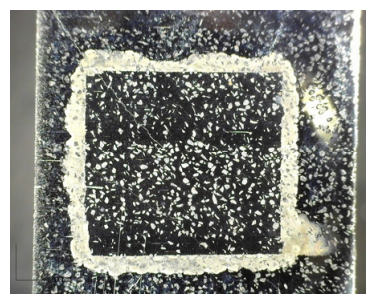

(e)

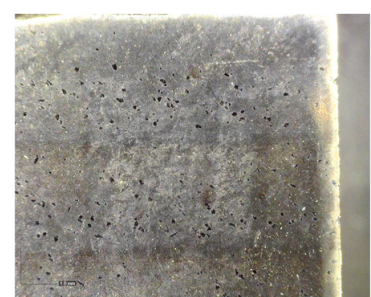

(b)

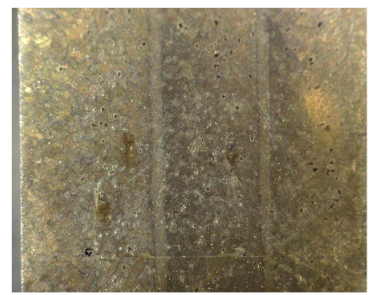

(f)

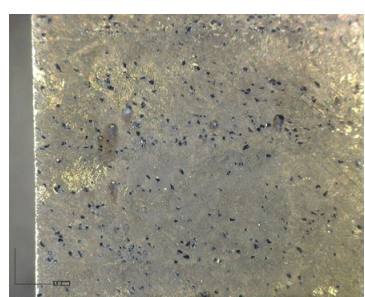

(c)

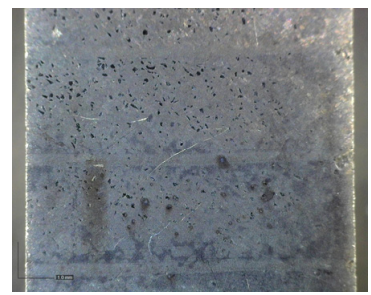

$(\mathrm{g})$

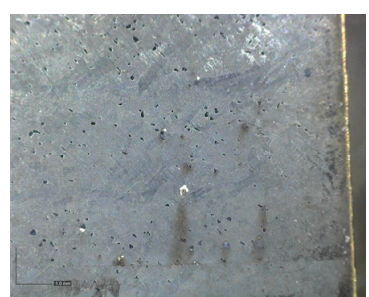

(d)

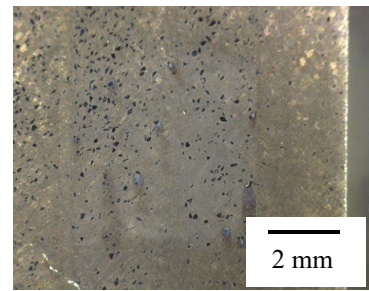

(h)

Figure 10. Surface morphologies after anodic polarization measurements of the as-deposited and nitrided layers with various WC compositions and nitriding temperatures: (a) WC $20 \mathrm{wt} . \%$ with as-deposited, (b) WC $20 \mathrm{wt} . \%$ at $400{ }^{\circ} \mathrm{C}$, (c) WC 20 wt. $\%$ at $425{ }^{\circ} \mathrm{C}$, (d) WC 20 wt. $\%$ at $450{ }^{\circ} \mathrm{C}$, (e) WC 40 wt. $\%$ with as-deposited, (f) WC 40 wt. $\%$ at $400{ }^{\circ} \mathrm{C}$, (g) WC 40 wt. $\%$ at $425{ }^{\circ} \mathrm{C}$, and (h) WC $40 \mathrm{wt} . \%$ at $450{ }^{\circ} \mathrm{C}$.

\subsection{Summary and Perspectives}

Nitriding as heat treatments has been applied to steel materials and has been highly effective in improving their properties. On the other hand, several papers about nitriding for stainless steel and other steel materials produced by laser cladding, selective laser melting and powder bed fusion, have been published on the improvement of wear and other properties [53-56]. In this study, it was found for the first time that the WC composite stainless steel layers have dendritic secondary carbides and dissolved tungsten, but the S-phase is formed by low-temperature plasma nitriding. In addition, not only a nitriding S-phase was formed, but also a carburizing S-phase was simultaneously formed by free carbon decomposed from WC particles. Owing to the nitrocarburizing, the S-phase thickened, and the hardness depth profiles were improved. This nitrocarburizing S-phase formed by nitriding alone is a unique phenomenon.

Recently, laser cladding and DED can be applied for an additive manufacturing as well as coatings. In these applications, there is a high demand for improved properties such as wear and corrosion resistance. As for steel materials, various heat treatment technologies have been developed and put into practical use to improve the characteristics. It is expected that heat treatment technologies will be applied to laser cladding and DED, contributing to the industry by expanding its applications.

\section{Conclusions}

In this study, we attempted to investigate whether low-temperature plasma nitriding applied to improving the hardness and corrosion resistance of AISI 316 L stainless steelbased WC composite layers fabricated by laser cladding. The effects of tungsten and tungsten carbides on the S-phase, which has not yet been clarified, were investigated. During laser cladding process, free carbon was produced by the decomposition of WC particles. Then, we attempted to form a nitrocarburizing S-phase by plasma nitriding alone using this free carbon. For these purposes, the metallurgical structure changes in the AISI 316 L stainless steel by WC particle dissolution during laser cladding, were examined in 
detail. The formation mechanism of the S-phase was discussed, and the hardness and corrosion resistance were evaluated.

1. $\mathrm{W}_{2} \mathrm{C}, \mathrm{M}_{6} \mathrm{C}$, and $\mathrm{M}_{12} \mathrm{C}$ were synthesized in the as-deposited layers during the laser cladding process because the WC particles decomposed and reacted with the AISI $316 \mathrm{~L}$ steel matrix. The AISI $316 \mathrm{~L}$ steel matrix became a dendritic structure, and secondary carbides were distributed in a network. In addition, tungsten was dissolved in the austenite of the steel matrix;

2. Free carbon was also produced during the laser cladding process. By low-temperature plasma nitriding, this free carbon was pushed inward by the diffused nitrogen, forming a carburizing S-phase. Consequently, the S-phase became a dual layer, the nitriding layer sited at the outside, and the carburizing layer at the inside;

3. Owing to the nitrocarburizing, the thickness of the S-phase was greater than that of the single AISI $316 \mathrm{~L}$ steel layer without WC. In the WC $40 \mathrm{wt} . \%$ layers, secondary carbides densely precipitated, and the grain size was small, which would prevent the nitrogen diffusion. As a result, the WC $20 \mathrm{wt}$.\% layers had thick S-phase compared with the WC 40 wt.\% layers;

4. The Vickers hardness of the surfaces was improved to the range of 1200 to $1400 \mathrm{HV}$ by low-temperature plasma nitriding. This hardness was almost the same as that of the S-phase on the single AISI $316 \mathrm{~L}$ steel layer without WC. The WC $40 \mathrm{wt} . \%$ layers were of a low hardness compared with the WC $20 \mathrm{wt} . \%$ layers, because the many secondary carbides with a low hardness were present. Meanwhile, the hardness depth profiles were improved to gradually decrease in the depth direction by the nitrocarburizing S-phase. This is expected to enhance the wear resistance and prevent the delamination of the S-phase layer from the substrate;

5. The corrosion resistance of the as-deposited layers was degraded due to the WC particle composite. In contrast, the nitrided layers exhibited a low current density, and those surfaces after the anodic polarization measurements showed a slight color change, with no major damage such as pitting corrosion. Accordingly, lowtemperature plasma nitriding of the WC composite layers improved the corrosion resistance to a generally excellent degree. The corrosion current density of the 40 wt. \% layers was higher than that of the WC $20 \mathrm{wt} . \%$ layers because containing more secondary carbides and $\mathrm{CrN}$.

Author Contributions: Conceptualization, S.A.; methodology, S.A.; investigation, S.A., T.Y. and N.U.; resources, S.A.; data curation, S.A.; formal analysis, S.A.; writing-original draft preparation, S.A.; writing-review and editing, S.A.; visualization, S.A.; supervision, S.A.; project administration, S.A.; funding acquisition, S.A. All authors have read and agreed to the published version of the manuscript.

Funding: This research was funded by JSPS KAKENHI, grant number 18K04792.

Conflicts of Interest: The authors declare no conflict of interest.

\section{References}

1. Desale, G.R.; Paul, C.P.; Gandhi, B.K.; Jain, S.C. Erosion wear behavior of laser clad surfaces of low carbon austenitic steel. Wear 2009, 266, 975-987. [CrossRef]

2. Bandyopadhyay, A.; Zhang, Y.; Bose, S. Recent developments in metal additive manufacturing. Curr. Opin. Chem. Eng. 2020, 28, 96-104. [CrossRef] [PubMed]

3. DebRoy, T.; Wei, H.L.; Zuback, J.S.; Mukherjee, T.; Elmer, J.W.; Milewski, J.O.; Beese, A.M.; Wilson-Heid, A.; De, A.; Zhang, W. Additive manufacturing of metallic components_Process, structure and properties. Prog. Mater. Sci. 2018, 92, 112-224. [CrossRef]

4. Smelov, V.G.; Sotov, A.V.; Murzin, S.P. Particularly selective sintering of metal powders by pulsed laser radiation. Key Eng. Mater. 2016, 685, 403-407. [CrossRef]

5. Toyserkani, E.; Khajepour, A.; Corbin, S. 3-D finite element modeling of laser cladding by powder injection: Effects of laser pulse shaping on the process. Opt. Lasers Eng. 2004, 41, 849-867. [CrossRef]

6. El Cheikh, H.; Courant, B.; Branchu, S.; Huang, X.; Hascot, J.Y.; Guillen, R. Direct Laser Fabrication process with coaxial powder projection of 316L steel. Geometrical characteristics and microstructure characterization of wall structure. Opt. Lasers Eng. 2012, 50, 1779-1784. [CrossRef] 
7. Thompson, S.M.; Bian, L.; Shamsaei, N.; Yadollahi, A. An overview of Direct Laser Deposition for additive manufacturing; Part I: Transport phenomena, modeling and diagnostics. Addit. Manuf. 2015, 8, 36-62. [CrossRef]

8. Moradi, M.; Ashoori, A.; Hasani, A. Additive manufacturing of stellite 6 superalloy by direct laser metal deposition-Part 1: Effects of laser power and focal plane position. Opt. Laser Technol. 2020, 131, 106328. [CrossRef]

9. Zhu, L.; Xue, P.; Lan, Q.; Meng, G.; Ren, Y.; Yang, Z.; Xu, P.; Liu, Z. Recent research and development status of laser cladding: A review. Opt. Laser Technol. 2021, 138, 106915. [CrossRef]

10. Majumdar, J.D.; Pinkerton, A.; Liu, Z.; Manna, I.; Li, L. Mechanical and electrochemical properties of multiple-layer diode laser cladding of 316L stainless steel. Appl. Surf. Sci. 2005, 247, 373-377. [CrossRef]

11. Bartkowski, D.; Młynarczak, A.; Piasecki, A.; Dudziak, B.; Gościański, M.; Bartkowska, A. Microstructure, microhardness and corrosion resistance of Stellite-6 coatings reinforced with WC particles using laser cladding. Opt. Laser Technol. 2015, 68, 191-201. [CrossRef]

12. Guo, C.; Zhou, J.; Chen, J.; Zhao, J.; Yu, Y.; Zhou, H. High temperature wear resistance of laser cladding NiCrBSi and NiCrBSi/WCNi composite coating. Wear 2011, 270, 492-498. [CrossRef]

13. Zhou, S.; Dai, X.; Zheng, H. Microstructure and wear resistance of Fe-based WC coating by multi-track over lapping laser induction hybrid rapid cladding. Opt. Laser Technol. 2012, 44, 190-197. [CrossRef]

14. Mertens, A.; L'Hoest, T.; Magnien, J.; Carrus, R.; Lecomte-Beckers, J. On the elaboration of metal-ceramic composite coatings by laser cladding. Mater. Sci. Forum 2017, 879, 1288-1293. [CrossRef]

15. Mertens, A.I.; Lecomte-Beckers, J. On the role of interfacial reactions, dissolution and secondary precipitation during the laser additive manufacturing of metal matrix composites: A review. New Trends 3D Print. 2016, 187-213. [CrossRef]

16. Wang, Z.; Tan, M.; Wang, J.; Zeng, J.; Zhao, F.; Xiao, X.; Xu, S.; Liu, B.; Gong, L.; Sui, Q.; et al. Core-shell structural iron based metal matrix composite powder for laser cladding. J. Alloys Compd. 2021, 878, 160127. [CrossRef]

17. Xiao, Q.; Sun, W.; Yang, K.; Xing, X.; Chen, Z.; Zhou, H.; Lu, J. Wear mechanisms and micro-evaluation on WC particles investigation of WC-Fe composite coatings fabricated by laser cladding. Surf. Coat. Technol. 2021, 420, 127341. [CrossRef]

18. Majumdar, J.D.; Kumar, A.; Li, L. Direct laser cladding of SiC dispersed AISI 316L stainless steel. Tribol. Int. 2009, 42, 750-753. [CrossRef]

19. Wu, C.L.; Zhang, S.; Zhang, C.H.; Zhang, J.B.; Liu, Y. Formation mechanism and phase evolution of in situ synthesizing TiC-reinforced 316L stainless steel matrix composites by laser melting deposition. Mater. Lett. 2018, 217, 304-307. [CrossRef]

20. Pejakovic, V.; Berger, L.M.; Thiele, S.; Rojacz, H.; Ripoll, M.R. Fine grained titanium carbonitride reinforcements for laser deposition processes of 316L boost tribocorrosion resistance in marine environments. Mater. Des. 2021, 207, 109847. [CrossRef]

21. Fetni, S.; Enrici, T.M.; Niccolini, T.; Tran, S.H.; Dedry, O.; Jardin, R.; Duchene, L.; Mertens, A.; Habraken, A.M. 2D thermal finite element analysis of laser cladding of 316L + WC composite coatings. Procedia Manuf. 2020, 50, 86-92. [CrossRef]

22. Enrici, T.M.; Dedry, O.; Boschini, F.; Tchuindjang, J.T.; Mertens, A. Microstructural and thermal characterization of 316L + WC composite coatings obtained by laser cladding. Adv. Eng. Mater. 2020, 22, 2000291. [CrossRef]

23. Fetni, S.; Enrici, T.M.; Niccolini, T. Thermal model for the directed energy deposition of composite coatings of 316L stainless steel enriched with tungsten carbides. Mater. Des. 2021, 204, 109661. [CrossRef]

24. Lu, J.Z.; Caa, J.; Lu, H.F.; Zhang, L.Y.; Luo, K.Y. Wear properties and microstructural analyses of Fe-based coatings with various WC contents on H13 die steel by laser cladding. Surf. Coat. Technol. 2019, 369, 228-237. [CrossRef]

25. Bartkowski, D.; Bartkowska, A.; Jurci, P. Laser cladding process of Fe/WC metal matrix composite coatings on low carbon steel using Yb: YAG disk laser. Opt. Laser Technol. 2021, 136, 106784. [CrossRef]

26. Wang, J.; Li, L.; Tao, W. Crack initiation and propagation behavior of WC particles reinforced Fe-based metal matrix composite produced by laser melting deposition. Opt. Laser Technol. 2016, 82, 170-182. [CrossRef]

27. Adachi, S.; Ueda, N. Formation of S-phase layer on plasma sprayed AISI 316L stainless steel coating by plasma nitriding at low temperature. Thin Solid Films 2012, 523, 11-14. [CrossRef]

28. Adachi, S.; Ueda, N. Surface hardness improvement of plasma-sprayed AISI 316L stainless steel coating by low-temperature plasma carburizing. Adv. Powder Technol. 2013, 24, 818-823. [CrossRef]

29. Adachi, S.; Ueda, N. Formation of expanded austenite on a cold-sprayed AISI 316L coating by low-temperature plasma nitriding. J. Therm. Spray Technol. 2015, 24, 1399-1407. [CrossRef]

30. Adachi, S.; Egawa, M.; Yamaguchi, T.; Ueda, N. Low-temperature plasma nitriding for austenitic stainless steel layers with various nickel contents fabricated via direct laser metal deposition. Coatings 2020, 10, 365. [CrossRef]

31. Borgioli, F. From austenitic stainless steel to expanded austenite-S phase: Formation, characteristics and properties of an elusive metastable phase. Metals 2020, 10, 187. [CrossRef]

32. Borgioli, F.; Galvanetto, E.; Bacci, T. Corrosion behaviour of low temperature nitrided nickel-free, AISI 200 and AISI 300 series austenitic stainless steels in $\mathrm{NaCl}$ solution. Corros. Sci. 2018, 136, 352-365. [CrossRef]

33. Huang, Z.; Guo, Z.X.; Liu, L.; Guo, Y.Y.; Chen, J.; Zhang, Z.; Li, J.L.; Li, Y.; Zhou, Y.W.; Liang, Y.S. Structure and corrosion behavior of ultra-thick nitrided layer produced by plasma nitriding of austenitic stainless steel. Surf. Coat. Technol. 2021, 405, 126689. [CrossRef]

34. Liu, H.Y.; Che, H.L.; Li, G.B.; Lei, M.K. Low-pressure hollow cathode plasma source carburizing technique at low temperature. Surf. Coat. Technol. 2021, 422, 127511. [CrossRef] 
35. Li, L.; Yan, J.; Xiao, J.; Sun, L.; Fan, H.; Wang, J. A comparative study of corrosion behavior of S-phase with AISI 304 austenitic stainless steel in $\mathrm{H}_{2} \mathrm{~S} / \mathrm{CO}_{2} / \mathrm{Cl}$ - media. Corros. Sci. 2021, 187, 109472. [CrossRef]

36. Sun, Y. Hybrid plasma surface alloying of austenitic stainless steels with nitrogen and carbon. Mater. Sci. Eng. A 2005, 404, 124-129. [CrossRef]

37. Adachi, S.; Ueda, N. Combined plasma carburizing and nitriding of sprayed AISI 316L steel coating for improved wear resistance. Surf. Coat. Technol. 2014, 259, 44-49. [CrossRef]

38. Adachi, S.; Ueda, N. Wear and corrosion properties of cold-sprayed AISI 316L coatings treated by combined plasma carburizing and nitriding at low temperature. Coatings 2018, 8, 456. [CrossRef]

39. Fernandes, F.A.P.; Casteletti, L.C.; Gallego, J. Microstructure of nitrided and nitrocarburized layers produced on a superaustenitic stainless steel. J. Mater. Res. Technol. 2013, 2, 158-164. [CrossRef]

40. Menthe, E.; Rie, K.-T.; Schultze, J.W.; Simson, S. Structure and properties of plasma-nitrided stainless steel. Surf. Coat. Technol. 1995, 74, 412-416. [CrossRef]

41. Buhagiar, J.; Li, X.; Dong, H. Formation and microstructural characterisation of S-phase layers in Ni-free austenitic stainless steels by low-temperature plasma surface alloying. Surf. Coat. Technol. 2009, 204, 330-335. [CrossRef]

42. Wydorska, K.M.; Kabulska, F.I.; Flis, J. Corrosion of low-temperature nitrided molybdenum-bearing stainless steels. Corros. Sci. 2011, 53, 1762-1769. [CrossRef]

43. Lee, E.S.; Park, W.J.; Jung, J.Y.; Ahn, S. Solidification microstructure and M2C carbide decomposition in a spray-formed high-speed steel. Metall. Mater. Trans. A 1998, 29, 1395-1404. [CrossRef]

44. Zhou, S.; Xu, T.; Hu, C.; Wu, H.; Liu, H.; Ma, X. A comparative study of tungsten carbide and carbon nanotubes reinforced Inconel 625 composite coatings fabricated by laser cladding. Opt. Laser Technol. 2021, 140, 106967. [CrossRef]

45. Bergstrom, M. The eta-carbides in the quaternary system Fe-W-C-Cr at $1250{ }^{\circ} \mathrm{C}$. Mater. Sci. Eng. 1977, 27, 271-286. [CrossRef]

46. Moller, W.; Parascandola, S.; Telbizova, T.; Gunzel, R.; Richter, E. Surface processes and diffusion mechanisms of ion nitriding of stainless steel and aluminium. Surf. Coat. Technol. 2001, 136, 73-79. [CrossRef]

47. Riviere, J.P.; Meheust, P.; Villain, J.P.; Templier, C.; Cahoreau, M.; Abrasonis, G.; Pranevicius, L. High current density nitrogen implantation of an austenitic stainless steel. Surf. Coat. Technol. 2002, 158-159, 99-104. [CrossRef]

48. Czerwiec, T.; Andrieux, A.; Marcos, G.; Michel, H.; Bauer, P. Is "expanded austenite" really a solid solution? Mossbauer observation of an annealed AISI 316L nitrided sample. J. Alloys Compd. 2019, 811, 151972-151983. [CrossRef]

49. Martínez, S.; Lamikiz, A.; Ukar, E.; Calleja, A.; Arrizubieta, J.A.; Lopez de Lacalle, L.N. Analysis of the regimes in the scannerbased laser hardening process. Opt Lasers Eng. 2017, 90, 72-80. [CrossRef]

50. Sun, Y.; Haruman, E. Effect of carbon addition on low-temperature plasma nitriding characteristics of austenitic stainless steel. Vacuum 2006, 81, 114-119. [CrossRef]

51. Okamoto, H. The effect of tungsten and molybdenum on the perfomance of super duplex stainless steels. In Proceedings of the Applications of Stainless Steel '92 Conference, Stockholm, Sweden, 9-11 June 1992; Volume 1, pp. 360-369.

52. Langberg, M.; Ornek, C.; Zhang, F.; Cheng, J.; Liu, M.; Granas, E.; Wiemann, C.; Gloskovskii, A.; Matveyev, Y.; Kulkarni, S. Characterization of native oxide and passive film on Austenite/Ferrite phases of duplex stainless steel using synchrotron HAXPEEM. J. Electrochem. Soc. 2019, 166, C3336-C3340. [CrossRef]

53. Godec, M.; Donik, Č.; Kocijan, A.; Podgornik, B.; Skobir Balantič, D.A. Effect of post-treated low-temperature plasma nitriding on the wear and corrosion resistance of 316L stainless steel manufactured by laser powder-bed fusion. Addit. Manuf. 2020, 32, 101000-101008. [CrossRef]

54. Dai, S.; Zuo, D.; Fang, C.; Zhu, L.; Cheng, H.; Gao, Y.-X.; Li, W.-W. Characteration of laser cladded Fe-Mn-Cr alloy coat ings modied by plasma nitriding. Mater. Trans. 2016, 57, 539-543. [CrossRef]

55. Hong, Y.; Dong, D.D.; Lin, S.S.; Wang, W.C.; Tang, M.; Kuang, T.C.; Dai, M.J. Improving surface mechanical properties of the selective laser melted 18Ni300 maraging steel via plasma nitriding. Surf. Coat. Technol. 2021, 406, 126675. [CrossRef]

56. Li, B.; Zhu, H.; Qiu, C.; Gong, X. Laser cladding and in-situ nitriding of martensitic stainless steel coating with striking performance. Mater. Lett. 2020, 259, 126829. [CrossRef] 